\title{
Correction to: Female reproductive organs of Brassica napus are more sensitive than male to transient heat stress
}

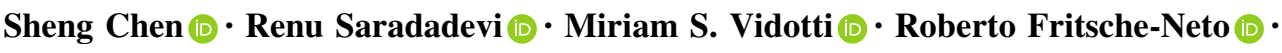 \\ Jose Crossa $(\mathbb{D} \cdot$ Kadambot H. M. Siddique $(\mathbb{D} \cdot$ - Wallace A. Cowling $(\mathbb{D}$
}

Accepted: 21 June 2021 / Published online: 21 July 2021

(C) The Author(s) 2021

\section{Correction to: \\ Euphytica (2021) 217:117 \\ https://doi.org/10.1007/s10681-021-02859-z}

The article Female reproductive organs of Brassica napus are more sensitive than male to transient heat stress, written by Sheng Chen, Renu Saradadevi, Miriam S. Vidotti, Roberto Fritsche-Neto, Jose Crossa, Kadambot H. M. Siddique, Wallace A. Cowling, was originally published Online First

The original article can be found online at https:// doi.org/10.1007/s10681-021-02859-z.

S. Chen $(\bowtie) \cdot$ R. Saradadevi .

K. H. M. Siddique · W. A. Cowling

The UWA Institute of Agriculture, The University of Western Australia, Perth, WA 6001, Australia

e-mail: sheng.chen@uwa.edu.au

S. Chen - R. Saradadevi - K. H. M. Siddique ·

W. A. Cowling

UWA School of Agriculture and Environment,

The University of Western Australia, Perth,

WA 6001, Australia

M. S. Vidotti - R. Fritsche-Neto

Department of Genetics, Luiz de Queiroz Agriculture College, University of São Paulo, Piracicaba,

SP, Brazil

J. Crossa

International Maize and Wheat Improvement Center

(CIMMYT), Mexico City, Mexico without Open Access. After publication in volume 217: 117 the author decided to opt for Open Choice and to make the article an Open Access publication. Therefore, the copyright of the article has been changed to (C) The Author(s) 2021 and the article is forthwith distributed under the terms of the Creative Commons Attribution 4.0 International License, which permits use, sharing, adaptation, distribution and reproduction in any medium or format, as long as you give appropriate credit to the original author(s) and the source, provide a link to the Creative Commons licence, and indicate if changes were made.

The images or other third party material in this article are included in the article's Creative Commons licence, unless indicated otherwise in a credit line to the material. If material is not included in the article's Creative Commons licence and your intended use is not permitted by statutory regulation or exceeds the permitted use, you will need to obtain permission directly from the copyright holder.

To view a copy of this licence, visit http:// creativecommons.org/licenses/by/4.0/.

Open Access This article is licensed under a Creative Commons Attribution 4.0 International License, which permits use, sharing, adaptation, distribution and reproduction in any medium or format, as long as you give appropriate credit to the original author(s) and the source, provide a link to the Creative Commons licence, and indicate if changes were made. The images or other third party material in this article are included in the article's Creative Commons licence, unless indicated otherwise in a credit line to the material. If material is 
not included in the article's Creative Commons licence and your intended use is not permitted by statutory regulation or exceeds the permitted use, you will need to obtain permission directly from the copyright holder. To view a copy of this licence, visit http://creativecommons.org/licenses/by/4.0/.
Publisher's Note Springer Nature remains neutral with regard to jurisdictional claims in published maps and institutional affiliations. 